\title{
Ideological Education and Social Practice for Students of Secondary Vocational Schools During Vacation in the Situation of COVID-19 Epidemic
}

\author{
Chunying Zhang \\ School of Marxism, Shandong University of Technology, Zibo, China
}

Email address:

dyn_keylab@163.com

To cite this article:

Chunying Zhang. Ideological Education and Social Practice for Students of Secondary Vocational Schools During Vacation in the Situation of COVID-19 Epidemic. International Journal of Secondary Education. Vol. 9, No. 2, 2021, pp. 57-61. doi: 10.11648/j.ijsedu.20210902.14

Received: April 20, 2021; Accepted: June 1, 2021; Published: June 4, 2021

\begin{abstract}
At present, the COVID-19 epidemic prevention and control situation is still very serious. This has brought new challenges to the social practice activities in the holiday of secondary vocational students. In order to deepen the understanding of secondary vocational students to their major and to enhance the competitive advantage of employment, it is necessary to guide students to participate in holiday social practice. First of all, this paper analyzes the particularity of secondary vocational school students' training, and explores the dilemma that secondary vocational school students face in holiday social practice under the background of COVID-19 epidemic situation from the perspectives of students and enterprises. On this basis, it points the new requirements of social practice activities of secondary vocational students' vacation, and puts forward the new organization mode of social practice activities. Then, it gives the innovative content of students' holiday social practice activities, which are as follows: taking part in practice activities in enterprises suitable for their occupation, taking part in community practice activities nearby, staying in school to participate in school spiritual civilization construction activities, serving families, participating in multi-site volunteer service activities. Finally, the paper puts forward guidance and evaluation methods for holiday social practice activities under COVID-19 epidemic situation, providing basis for effective evaluation of the effect of holiday practice activities of secondary vocational students under the background of COVID-19 epidemic situation. This study helps to improve the practical ability and innovation ability of secondary vocational students, and provides effective support for strengthening their sense of social responsibility and fulfilling the mission of youth in the new era.
\end{abstract}

Keywords: Philosophical Thinking, Education, Social Practice, Secondary Vocational Schools

\section{Introduction}

The social practice of secondary vocational students is vacation practice or off-campus practice. Necessary social practice can give secondary vocational students more opportunities to integrate with the society. Social practice is of great significance in deepening secondary vocational students' understanding of their major, confirming that they are suitable for their career, preparing for the role transition from student to worker, and enhancing their competitive advantage in employment. Holiday social practice helps them to accumulate wisdom, showcase their talents, improve practical ability and innovation ability, constantly strengthen the sense of social responsibility, fulfill the mission of young people in the new era. At present, the COVID-19 epidemic prevention and control situation is still very serious. This has brought new challenges to the social practice activities in the holiday of secondary vocational students.

According to the existing literature, scholars mainly focus on the study of students' online learning under the background of COVID-19 epidemic, while there are few studies base on the social practice of secondary vocational students' holidays. or example, Zhang et al. studied the reality of experimental education for virtual cloud-to-terminal storage management [1]. Lacka et al. put forward the problem that digital technology can improve students' learning efficiency, and explored the application of virtual learning environment and college social media [2]. Lee et al. analyzed the education 
activities and the transition to family education during the epidemic period of COVID-19, and provided a useful reference for ideological education during home learning [3]. Qiu et al. studied how to promote tourism education under the background of COVID-19 [4]. Wijesooriya et al. studied telemedicine and education under the background of COVID-19, providing a useful reference for students' online education [5]. Mishra et al. conducted research on online teaching of colleges and universities during the COVID-19 pandemic blockade, and provided coping strategies for students' education under the sudden epidemic situation for college teachers and administrators [6-9].

The above research provides a useful reference for the social practice and education of secondary vocational students in the context of COVID-19 epidemic situation, but there is still a lot of research space [10-13]. Based on the particularity of secondary vocational school students' training, this paper carried out a study on the social practice and education of secondary vocational students' holidays under the background of COVID-19 epidemic prevention, to expect providing a useful reference for improving the ability and quality of secondary vocational students.

\section{The Particularity of Secondary Vocational School Student Training}

\subsection{The Particularity of Education Orientation of Secondary Vocational Schools}

Secondary vocational schools are schools that carry out secondary vocational education, and students of secondary vocational schools obtain a technical secondary school diploma after graduation It is the vocational education carried out in the stage of high school education, including some post-high school vocational training, which is the main part of vocational education. Its orientation is to train a large number of skilled personnel and high-quality workers on the basis of compulsory education. Secondary vocational schools carry out vocational knowledge and skills education in accordance with the requirements of vocational positions while providing students with cultural knowledge education at the high school level.

From the comparison between secondary vocational education and general education, although both belong to education, but it is a different type of education. With the view of its own system, vocational education is in the stage of high school education to vocational education, also including some vocational training after high school, it is the "basic education" in the vocational education, the education level and personnel training target reflecting the professional guidance, professional knowledge education and vocational education are of equal importance.

\subsection{The Particularity of Students in Secondary Vocational Schools}

As students of a special type of education, secondary vocational students have the common psychological and physiological characteristics as the same age group, and their differences are more concentrated in the role transformation, professional identity, learning attitude adjustment and other aspects caused by vocational education. Entering the secondary vocational, students first face the role transformation, that is, from middle school students to secondary vocational students, the transformation of cross-class education is not easy for secondary vocational students. Influenced by the role stereotypes formed in middle school, the role of secondary vocational students means many new challenges, often gathering very complex feelings.

\section{Difficulties Faced by Students of Secondary Vocational Schools in Holiday}

\subsection{Secondary Vocational Students}

Students are afraid of being infected with the COVID-19 virus during the social practice, so they worry about the social practice activities during the holiday. In addition, the enterprises that generally accept the social practice of secondary vocational students are small and medium-sized enterprises, and their management system needs to be further improved. Under such circumstances, students have doubts about whether companies can keep them safe.

\subsection{Enterprise}

Under the background of the COVID-19 epidemic [14, 15], the enterprise management is under great pressure. Many enterprises are not willing to take the corresponding responsibility for the safety of secondary vocational students during the practice of enterprises. Secondary vocational students are generally minors, they can not be like adult college students to think about the problem and deal with the problem. In the serious situation of epidemic prevention, most enterprises are unwilling to accept secondary vocational students to carry out social practice activities.

\section{New Requirements for Social Practice Activities in the Holidays of Secondary Vocational Students}

\subsection{Ensure the Dual Security of Practice and Epidemic Prevention}

All students should attach great importance to epidemic prevention in practical activities, strengthen safety knowledge education and special training on epidemic prevention, strictly abide by local requirements on epidemic prevention and control. Practice teams are forbidden to travel to high-risk areas for epidemic prevention, and in principle are not allowed to carry out social practice activities across provinces. It is necessary to pay close attention to the changes of epidemic 
situation, extreme weather and geological conditions in the service area, and prepare the contingency plan and disposal plan for emergencies.

\subsection{Take Crisis as an Opportunity and Pay Attention to Practical Results}

Each class should actively mobilize the students to take the initiative to participate in social practice and strengthen the effect of practice education. It can focus on the employment practice activities of entering enterprises, carry out social practice relying on scientific and technological innovation activities, and combine them with their own majors to hone professional skills and increase professional knowledge.

\subsection{Overcome Difficulties and Participate in Social Practice Nearby}

Due to the current epidemic prevention situation is still grim, in order to ensure their own safety, secondary vocational students should choose enterprises, communities nearby to participate in social practice. Even attending a social practice in a nearby area is a security risk. Therefore, on the one hand, we must encourage the students to participate in social practice, on the other hand, we must do well in the prevention epidemic prevention.

\section{The New Organization Mode of Students' Holiday Social Practice Activities}

The social practice during the holiday continues to adhere to the principle of being convenient to the nearest place, and is organized in the form of online "cloud team" and offline "back to hometown". On the premise of doing a good job and strictly observing the epidemic prevention and control requirements in practice, the school should actively build a practice platform based on the social practice and professional characteristics in vacation time, combine labor education with government affairs practice, volunteer service, innovation and entrepreneurship. We should reduce the radius of activities, actively explore the "cloud" model of social practice, strictly prohibit the organization of large-scale gatherings of people, and prohibit offline social practice in medium-high risk areas.

\section{Innovative Content of Students' Holiday Social Practice Activities}

\subsection{Participate in Practical Activities of Enterprises Suitable for Occupation}

Jointly carry out practical activities in enterprises with the recruitment and employment department, encourage students to contact successful entrepreneurs, famous alumni and offline visits to understand the employment situation in the society and the needs of enterprises. Combine vacation social practice with professional learning, according to their own reality and employment intentions, to lay a solid foundation for the future high-quality employment and entrepreneurship.

\subsection{Staying on Campus to Participate in Spiritual Civilization Construction Activities}

Encourage outstanding students to visit their Alma mater during the holidays to publicize the school's history, specialty setting, discipline characteristics and other advantages, show the good spirit of our students, and expand the popularity and social influence of our school. During the holidays, the practice teams are encouraged to report to the teachers and students of junior high schools about the school, campus life, professional learning, innovative practice, etc., through PPT, video display and other forms, and carry out activities such as school panorama overview, enrollment consultation and Q\&A, professional selection help, personal growth sharing, and professional learning exchange based on the reality. Through preaching, the school will fully show the school spirit and transfer the positive energy of inspirational talent.

\subsection{Family Service Activities}

Service activities for the family. Learn at least one family service skill during the holidays and make it a habit to serve your family. Guide students to help parents and elders at home to do what they can, cultivate students to take the initiative to undertake family responsibilities, consciously share the habit of housework, learn to take the initiative to care for parents and elders, cultivate feelings of gratitude to parents.

\subsection{Participate in Volunteer Service Activities in Multiple Venues}

We will take the holidays and festivals as an opportunity to promote the spirit of volunteers. We will focus on vulnerable groups in our hometown, such as empty-nesters, families who have lost their only child, the disabled, and left-behind children in rural areas. Encourage students to take an active part in volunteer service activities such as material consignment, passenger guidance, ticket guidance, information consultation and caring for special groups returning home during the Spring Festival travel rush. On the basis of ensuring their own safety, young students are encouraged to take an active part in local volunteer service teams for epidemic prevention and control, and carry out epidemic prevention publicity activities, checkpoint detection and guarding activities, etc.

\subsection{Conduct Social Research Activities During Holidays}

During holidays, students can go to the community level to pay close attention to social hot spots and various aspects of people's livelihood. We carried out research on epidemic prevention and control, rural revitalization, environmental pollution prevention and control, ecological progress, drug control and AIDS prevention, and produced high-quality research reports. Encourage extracurricular academic science and technology works competition as the orientation, with reference to the philosophy and social science competition 
guidelines for topic selection. In combination with the content of social practice of returning home during vacations, this paper finds out the achievements and deficiencies of social practice after vacations and explores the long-term mechanism of social practice in the form of returning to practice places and contacting practice objects.

\subsection{Scientific Research Activities Related to the Major}

Students are encouraged to actively carry out scientific and technological innovation activities and enhance their ability of scientific and technological innovation by relying on professional laboratories, innovation and entrepreneurship laboratories, practice bases and open and shared practical teaching platforms. In combination with the science and technology innovation and entrepreneurship competition, going into the laboratory to carry out the deep processing of the project, and further improved the project-related data, design and development, so as to achieve excellent results in the future competitions. In combination with the ideas of innovative projects, the university actively carries out scientific and technological exploration, has a wide understanding of scientific and technological innovation and patent application policies, and combines holiday social practice with laboratory projects and entrepreneurial practice to guide and motivate college students to make innovation.

\section{Guidance and Evaluation of Holiday Social Practice Activities Under the Background of Epidemic Situation}

\subsection{Guidance on Holiday Social Practice Activities in the Context of Epidemic Situation}

Invite instruct teachers, class tutors, counselors, etc. in the stages of project planning, activity development, education evaluation, guiding the organization of practical activities, and respond to members' harvest and confusion in the process of practice. During the preparation period of the activity, relevant activities should be trained and guided in advance, so as to strengthen safety awareness, ensure health, guarantee the orderly conduct of the activity. In the process of activities, we should pay attention to the management and support of team members to ensure the quality of each activity. Those who complete social practice activities within the prescribed time and submit the materials shall be given certain fund support. The expenses generated by social practice activities in which the details do not meet the requirements shall not be supported.

\subsection{Evaluation of Holiday Social Practice Activities in the Context of Epidemic Situation}

Select one or several contents of practice direction to carry out, making practice report. Students should establish a portfolio of personal social practice activities, which should contain all kinds of records and other supporting materials that can reflect the process of group and individual activities, and provide verification methods or channels. For example, the address and telephone number of the practice unit, the name and contact telephone number of the relevant personnel, etc. Activity attitude and activity harvest can be evaluated qualitatively, using descriptive words such as "excellent", "good", "average", "poor" and so on. For the students with strong sense of participation and innovation, diligent in practice, brave in exploration and sincere spirit of cooperation, they have made efforts and achieved fruitful harvest. The school will give special reward to the students who get excellent evaluation. If the social practice results are recognized by experts as having certain social benefits, scientific value or practical value, the school will give special rewards.

\section{Conclusions}

This paper analyzes the particularity of students' training in secondary vocational schools and explores the dilemma that students in secondary vocational schools face in holiday social practice under the background of epidemic situation. On this basis, it clarifies the new requirements of social practice activities of secondary vocational students' vacation, and puts forward the new organization mode of social practice activities of students' vacation. Then, it gives the innovative content of students' holiday social practice activities, which are as follows: taking part in practice activities in enterprises suitable for occupation, taking part in community practice activities nearby, staying in school to participate in school spiritual civilization construction activities, serving families, participating in multi-site volunteer service activities, etc. Finally, the paper puts forward guidance and evaluation methods for holiday social practice activities under the background of epidemic situation, providing basis for effective evaluation of the effect of holiday practice activities of secondary vocational students under the background of epidemic situation.

With the development of the society, the new technological revolution changes with each passing day, making the enterprise has undergone fundamental changes. At the same time, in addition to examining the basic skills of secondary vocational students, enterprises pay more attention to their development potential, ideological quality, values and other overall quality. In this case, the social practice of secondary vocational students is particularly important. Therefore, schools should pay attention to the cultivation of high quality talents, professional education and general education in vocational education organic combination. And the follow-up research needs to strengthen the deep integration of professional education and general education in the vacation practice of secondary vocational students.

\section{Acknowledgements}

This work was supported by the Scientific Research Foundation for Doctors (419067). 


\section{References}

[1] Hongxin Zhang, Jin Zhang, Xue Yin, et al. Cloud-to-end Rendering and Storage Management for Virtual Reality in Experimental Education. Virtual Reality \& Intelligent Hardware 2020 V1 2 Issue 4368-380.

[2] Evelina Lacka, T. C. Wong, Mohamed Haddoud. Can Digital Technologies Improve Students' Efficiency? Exploring the role of Virtual Learning Environment and Social Media use in who Education $[\mathrm{J}]$. Journal of Computers Education, https://doi.org/10.1016/j.compedu.2020.104099.

[3] Shawna J. Lee, Kaitlin P. Ward, Olivia D. Chang, Kasey M. Downing. Parenting Activities and the Transition to Home-based Education During the COVID-19 Pandemic [J]. Children and Youth services Review. DOI: https://doi.org/10.1016/j.childyouth.2020.105585.

[4] Hanqin Qiu, Qinghui Li, Chenxi Li. How technology facilitates tourism education in COVID-19: case study of nankai University. Journal of Hospitality, Leisure, Sport and Tourism Education. https://doi.org/10.1016/j.jhlste.2020.100288.

[5] N. Romesh Wijesooriya, Vimal Mishra. Paul L. P. Brand. COVID-19 and Telehealth, Education, and Research Adaptations. Paediatric Respiratory Reviews. 35 (2020) 38 -42.

[6] Lokanath Mishra, Tushar Gupta, Abha Shree. Online teaching-learning in higher education during lockdown period of COVID-19 pandemic. International Journal of Educational Research Open 1 (2020) 100012.

[7] Adnan, M. (2020). Online learning amid the COVID-19 pandemic: Students perspectives. J. Pedagog. Res., 2, 45-51.
[8] Aguilera-Hermida, A. P. (2020). College students' use and acceptance of emergency online learning due to COVID-19. International Journal of Educational Research Open 1. https://doi.org/10.1016/j.ijedro.2020.100011.

[9] Ali, W. (2020). Online and remote learning in higher education institutes: A necessity in light of COVID-19 pandemic. High. Educ. Stud., 10, 16.

[10] Li, Q.; Miao, Y.; Zeng, X.; et al. (2020). Prevalence and factors for anxiety during the coronavirus disease 2019 (COVID-19) epidemic among the teachers in China. Journal of Affective Disorders, 277, 153-158.

[11] Becker, S. P.; Breaux, R.; Cusick, C. N. et al. (2020). Remote learning during COVID-19: Examining school practices, service continuation, and difficulties for adolescents with and without attention-deficit/hyperactivity disorder. Journal of Adolescent Health, 67, 769-777.

[12] Morgan, H. (2020). Best practices for implementing remote learning during a pandemic. Clear. House A J. Educ. Strateg. Issues Ideas, 93, 135-141.

[13] Dhanalakshmi, R.; Anuja Mary, A.; Shrijith D.; et al. (2021). A study on COVID-19 - Impacting Indian education, Materials Today: https://doi.org/10.1016/j.matpr.2021.02.786.

[14] Doghonadze, N.; Aliyev, A.; Halawachy, H.; Knodel, L.; Adedoyin, A. S. (2020). The degree of readiness to total distance learning in the face of COVID-19-Teachers' view (case of Azerbaijan, Georgia, Iraq, Nigeria, UK and Ukraine). J. Educ. Black Sea Reg., 5, 2-41.

[15] Freeman, S.; Nguyen, T.; Beliveau, J.; et al. (2021). COVID-19 response strategies at large institutes of higher education in the United States: A landscape analysis, Fall 2020. Journal of Adolescent Health 68, 683-685. 